\title{
Comparison of computed tomography and thoracic radiography findings for the assessment of pulmonary diseases in dogs
}

\author{
Başak BOZTOK ÖZGERMEN ${ }^{1}$, Ali BUMIN ${ }^{2}$ \\ ${ }^{1}$ Aksaray University, Faculty of Veterinary Medicine, Department of Surgery, Aksaray; ${ }^{2}$ Ankara University, Faculty of Veterinary \\ Medicine, Department of Surgery, Ankara, Turkey.
}

\begin{abstract}
Summary: Radiographic examination is a common method for diagnosis of pulmonary diseases but it is not always adequate for accurate diagnosis. Therefore, an advanced imaging method as computed tomography (CT) was used in this study for veterinary purposes. This study aimed the comparison of the two imaging methods for evaluation of pulmonary diseases in dogs. 20 dogs of various breeds, age and sex with complaints of lung disease made up the materials of the study. Following the patient history and clinical examination, radiographic examination and CT examination were performed and the outcomes were evaluated. Pulmonary nodules/masses or calcified foci in 12 patients, pleural effusion and pneumothorax in 4 patients, pulmonary edema in 2 patients, tracheal collapse and megaesophagus in two patients were diagnosed by using both radiographic and CT examination. As a conclusion, radiographic examination provides an initial diagnosis for severe diseases and can be used as first imaging modality for lung diseases, but CT has superiority over radiography due to its ability to provide cross-sectional images and more accurate diagnosis.
\end{abstract}

Keywords: Computed tomography, dog, pulmonary diseases, thoracic diseases, thoracic radiography.

\section{Köpeklerde akciğer hastalıklarının tanısında bilgisayarlı tomografi ve torasik radyografi bulgularının karşılaştırılması}

Özet: Akciğer hastalıklarının tanısında radyografik muayene sıklıkla kullanılan bir yöntemdir; ancak kesin tanı için yetersiz kalmaktadır. Bu çalışmada ileri görüntüleme yöntemi olan bilgisayarlı tomografi, veteriner amaçlı kullanılmıştır. Çalışmada, bahsi geçen iki görüntüleme yönteminin akciğer hastalıklarında birbirlerine olan üstünlügü karşılaştırılmıştır. Solunum şikayeti ile kliniğe başvuran çeşitli ırk, yaş ve cinsiyetteki 20 köpek çalışmaya dahil edilmiştir. Hastalara ait anamnez bilgileri alınıp klinik muayeneleri yapıldıktan sonra, radyografik muayene ve bunu takiben bilgisayarlı tomografi ile inceleme yapılmıştır. On iki hastaya pulmoner nodül, kitle ya da kalsifiye odak, dört hastaya plöral efüzyon ve pnömotoraks, iki hastaya pulmoner ödem ve iki hastaya trakeal kollaps ve megaözofagus tanısı hem radyografik hem de BT muayenesi sonucunda konulmuştur. Sonuç olarak, radyografi akciğer hastalıklarında öncül tanı konulması amacıyla ilk görüntüleme yöntemi olarak kullanılabilir. Bilgisayarlı tomografide kesit görüntü elde edilebilmesi sonucunda, kesin tanıya giden yolda radyografiye olan üstünlüğü ortaya konmuştur.

Anahtar sözcükler: Akciğer hastalıkları, bilgisayarlı tomografi, köpek, toraks hastalıkları, toraks radyografisi.

\section{Introduction}

Computed tomography (CT) currently plays an important role in the diagnosis and evaluation of many human diseases. In veterinary practice, it is becoming more widespread as technology advances.

The respiratory system is one of the four vital systems in the body. Deterioration of respiratory function in animals can lead to serious life-threatening conditions and if treatment is not done in a short time it can result in death of the animal. In patients with severe respiratory distress a provisional diagnosis and preliminary treatment plan must be arranged. Medical history and physical examination findings of the patient can never be enough for a true diagnosis. The need for an imaging method is crucial for diagnosis of the disease. Patient's history and physical examination findings should be evaluated for determining the suitable imaging method to be used for a definitive diagnosis $(3,5,6)$.

Thoracic radiography can be used for determination of an intrathoracic disease or evaluation and diagnosis of a systemic disease (21). Thoracic radiography is a helpful method as a guide before performing complicated diagnostic imaging techniques such as $\mathrm{CT}(6,12)$.

High kilovoltage $(\mathrm{kV})$, low milliampereseconds (mAs) with short exposure time must be preferred for thoracic radiography. Exposure should be made at the end of the inspiratory phase when the lungs are inflated with air (21). Radiographs taken at the end of the expiration period may pretend pathological infiltrations due to increase in pulmonary opacity (8). 
Radiographic evaluation of thoracic structures (especially lungs) requires 3 projections: left and right lateral, ventrodorsal (VD) or dorsoventral (DV) (15). If cardiac structures are to be evaluated, right lateral and DV projections are required. For evaluation of parenchymal pathologies right lateral and VD, if pulmonary metastasis is suspected left and right lateral, VD projections must be used $(3,21)$.

CT is indicated in patients when imaging methods like radiography and/or ultrasonography fail to diagnose the disease $(9,22)$.

This study aimed the comparison of the two imaging methods for evaluation of pulmonary diseases in dogs, when the results of thoracic radiography are indeterminate or suspected to be false negative. The main objective was to determine if thoracic CT provided additional information regarding the presence, location and extent of the pathology. Finally, determination of superiority of the two methods for differential diagnosis was aimed.

\section{Materials and Methods}

20 dogs of various breeds, age and sex that were referred to Ankara University, Faculty of Veterinary Medicine radiodiagnostic unit, with complaints of pulmonary diseases were included in this study.

First the medical histories of the patients were obtained from the patient owners. Then, physical examination was performed by either Internal Diseases or Surgery specialists. After that radiographic evaluation of the thorax was made. Innomed brand, TOP-X HF model X-ray device was used for thoracic radiography. For deep-chested, large breeds $54 \mathrm{kV}, 20 \mathrm{mAs}$ and for middle sized dogs $50 \mathrm{kV}, 20 \mathrm{mAs}$ were used for exposure. Patients were sedated by xylazine hydrochloride (Alfazyne \%2, Ege Vet, İzmir, Turkey) administered $0.10 \mathrm{ml} / \mathrm{kg} \mathrm{BW}$ intramuscularly. Patients with severe respiratory distress were not sedated or anesthetized. Patients were positioned and images were obtained in right lateral, DV or VD projections. Kodak brand x-ray films of different sizes according to patient's size were used. Exposures were made at the end of the inspiratory phase. Following x-rays, CT evaluations of the patients were done. General Electric (GE Medical Systems, Milwaukee, WI brand, 2119734-2 model) spiral CT device was used for CT evaluation. Induction of anesthesia was made by administration of Propofol (Propofol \%1, $20 \mathrm{ml}$, Fresenius Kabi, Sweden) $6 \mathrm{mg} / \mathrm{kg}$ intravenously. General anesthesia was maintained by Sevoflurane (Sevorane liquid $250 \mathrm{ml}$, Aesica, UK) by AMS Junior $620 \mathrm{~V}$ automatic ventilation device and Shei brand Sevoflurane vaporisator. Scanning was performed from caudal to cranial. Slice width was 1-3 mm depending on the location of the lesion. Exposure time ranged from 40 to 60 seconds depending on the size of the patient. $120 \mathrm{kV}, 100-150 \mathrm{mAs}$, window level -100
$\mathrm{HU}$, window width $2000 \mathrm{HU}$ and pitch $=1$. Rimage 2000i 2 - series CD robot was used for obtaining CT images. This project was approved by Ankara University Local Animal Ethics Committee (2012-6-44).

\section{Results}

History of the patients: Ten patients (Patient no: 1, $2,3,6,8,11,12,16,18,20)$ included in this study had dyspnea. Five patients (Patient no: 1, 7, 16, 18, 19) had exercise intolerance, one patient (Patient no: 4) had abdominal respiration, one patient (Patient no: 8) had nasal discharge, six patients (Patient no: 1, 8, 12, 13, 18, 20) had dysphagia and anorexia.

Six of the patients (Patient no: 1, 3, 8, 9, 15, 17) had mammary tumors and only one of them (Patient no: 8 ) had mastectomy prior to radiologic examination. Patient number 5 had osteosarcoma in the right forearm. Patient number 14 had masses in the suprascapular, sternal and perianal regions. Patient number 2 was hit by a car. Patient number 11 fell from height.

Radiographic evaluation of the patients: Thoracic radiographic examination results of the patients with pulmonary nodules/masses or calcified foci were evaluated (Table 1). One of the patients had diffuse multiple mass lesions in the lung parenchyma. The diameter of the largest lesion was about $5 \mathrm{~cm}$ (Figure 1). Patient number 14 had a mass lesion with a diameter of 2 $\mathrm{cm}$ (Figure 2). Lateral radiography of patient number 18 revealed large mass lesions in the cranioventral and craniodorsal lung lobes (Figure 3).

Eight patients had pleural or other diseases (Table 2 ). In five patients pleural effusion was present. Due to the effusion around the cardiac area, cardiac silhouette couldn't be evaluated in patient number 4 (Figure 4). One patient had pneumothorax (Figure 5). A patient (Patient no: 16) had ventrodorsal tracheal collapse at the level of the $1^{\text {st }}$ thoracic vertebrae. In patient number 20, lung parenchyma was evaluated as normal but tracheal margins couldn't be clearly evaluated due to superimposition of the dilated esophagus.

CT evaluation of the patients: Seven patients had masses in the lung parenchyma. Patient number 1 had multiple nodules in the cranial, caudal and accessory lung lobe (Figure 6). These nodules were evaluated as mammary tumor metastasis. In patient number 10 , calcified foci that were seen on radiographs were found to be a nodule of $18 \mathrm{~mm}$ diameter. In patient number 5 , the lesion that was detected on radiographs was found to be a mass, associated with the left chest wall, $55.7 \times 82.4$ $\mathrm{mm}$ in size at the level of the $7^{\text {th }}$ thoracic vertebra, as well as two other metastasis that were not seen on radiographs. In patient number 18 transverse CT images taken at the level of tracheal bifurcation revealed a mass completely replacing the lung tissue in the right hemithorax (Figure 7). Pathologic examination of the mass confirmed thymoma. 
Table 1. Comparison of x-ray and CT findings of the patients with pulmonary nodules/masses or calcified foci.

Tablo 1. Pulmoner nodül/kitle veya kalsifiye odakları olan hastalarda radyografik ve BT bulgularının karşılaştırılması.

\begin{tabular}{|c|c|c|}
\hline \multirow{2}{*}{$\begin{array}{c}\text { Patient } \\
\text { no }\end{array}$} & \multicolumn{2}{|r|}{ Findings } \\
\hline & X-Ray & $\mathrm{CT}$ \\
\hline 1 & $\begin{array}{l}\text { Diffusely distributed multiple masses in the lung } \\
\text { parenchyma }\end{array}$ & $\begin{array}{l}\text { Multiple nodules in both right and left; cranial, caudal and } \\
\text { accessory lung lobes }\end{array}$ \\
\hline 5 & Metastasis. Solitary nodule $\left(10 \mathrm{~mm}\right.$, left $7^{\text {th }}$ ICS $\left.*\right)$ & $\begin{array}{l}2 \text { nodules }(30.3 \times 18.6 \mathrm{~mm} \text { and } 8.8 \times 7.1 \mathrm{~mm} \text {; associated with } \\
\text { the left and right chest wall, at the level of } \mathrm{T}_{4} \text {, respectively). } \\
\text { A hyperdense mass }(55.7 \times 82.4 \mathrm{~mm} \text {, associated with the left } \\
\left.\text { chest wall, at the level of } \mathrm{T}_{7}\right)\end{array}$ \\
\hline 7 & A mass lesion $\left(15 \mathrm{~mm}, 8^{\text {th }} \mathrm{ICS}\right)$ on lateral radiograph & $\begin{array}{l}\text { Hyperdense mass at both right caudal and accessory lung } \\
\text { lobes at the level of the } 8^{\text {th }} \text { ICS }\end{array}$ \\
\hline 8 & Miliary diffuse radiopaque foci & $\begin{array}{l}\text { Nodules }\left(3.26 \mathrm{~mm} \text {, at the level of } \mathrm{T}_{3} \text { ). }\right. \\
\text { Hyperdense masses (right and left lung parenchyma, at the } \\
\text { level of } \mathrm{T}_{6} \text { ) }\end{array}$ \\
\hline 9 & Multiple foci at $6^{\text {th }}$ ICS & $\begin{array}{l}\text { No mass lesion present. } \\
\text { Calcified foci }\left(3 \mathrm{~mm} \text {, right and left, at the level of } \mathrm{T}_{6}\right)\end{array}$ \\
\hline 10 & $\begin{array}{l}\text { Calcified foci (left } 6^{\text {th }}, 7^{\text {th }}, 10^{\text {th }} \text { ICS and } 7^{\text {th }} \text { and right } \\
8^{\text {th }} \text { ICS) }\end{array}$ & A hyperdense nodule $\left(18 \mathrm{~mm}\right.$, right $\left.7^{\text {th }} \mathrm{ICS}\right)$ \\
\hline 13 & Normal lung parenchyma & $\begin{array}{l}\text { Calcified foci (not larger than } 10 \mathrm{~mm} \text { in size, left and right, at } \\
\text { the level of } \mathrm{T}_{2} \text {; dorsal of the right cranial lung lobe, at the } \\
\text { level of } \mathrm{T}_{4} \text {; left caudal lung lobe, at the level of } \mathrm{T}_{5} \text { and left } \\
\text { caudal lung lobe, at the level of } \mathrm{T}_{7} \text { ) }\end{array}$ \\
\hline 14 & A mass lesion $\left(20 \mathrm{~mm}, 8^{\text {th }} \mathrm{ICS}\right)$ & $\begin{array}{l}\text { Nodules (17.7 x } 19.2 \mathrm{~mm} \text {, left caudal lung lobes; } 20.65 \mathrm{x} \\
12.86 \mathrm{~mm} \text {, right caudal lung lobes, respectively) }\end{array}$ \\
\hline 15 & A mass lesion $\left(10 \mathrm{~mm}, 5^{\text {th }} \mathrm{ICS}\right)$ & Nodule $\left(6 \times 4 \mathrm{~mm}\right.$, right lung lobe, at the level of $\left.\mathrm{T}_{4}\right)$ \\
\hline 17 & A calcified focus (right, at the level of $\mathrm{T}_{7}$ ) & $\begin{array}{l}5 \text { calcified foci ( } 4 \text { at right caudal lobe; } 1 \text { at left caudal lung } \\
\text { lobe, at the level of } \mathrm{T}_{7} \text { ) }\end{array}$ \\
\hline 18 & $\begin{array}{l}\text { Large mass lesions in the cranioventral and } \\
\text { craniodorsal lung lobes }\end{array}$ & $\begin{array}{l}\text { Large mass completely covering right hemithorax at the level } \\
\text { of the tracheal bifurcation, only left hemithorax can be seen. } \\
\text { Heart lifted away from the sternum and deviated dorsally at } \\
\text { the level of } \mathrm{T}_{8}\end{array}$ \\
\hline 19 & Calcified focus in the dorsal lung lobes & $\begin{array}{l}\text { Calcified foci (right and left lung lobes, at the level of } \mathrm{T}_{4} \text { and } \\
\mathrm{T}_{6} \text { ) }\end{array}$ \\
\hline
\end{tabular}

[*ICS: intercostal space. T: Thoracic vertebra]

Table 2. Comparison of x-ray and CT findings of the patients with pleural or other diseases.

Tablo 2. Plöral ya da diğer hastalığı olan olgularda, radyografik ve BT bulgularının karşılaştırılması.

\begin{tabular}{|c|c|c|}
\hline \multirow{2}{*}{$\begin{array}{c}\text { Patient } \\
\text { no }\end{array}$} & \multicolumn{2}{|c|}{ Findings } \\
\hline & X-Ray & $\mathrm{CT}$ \\
\hline 2 & $\begin{array}{l}\text { Pneumothorax. Cardiac silhouette was elevated from } \\
\text { the sternum. }\end{array}$ & Pneumothorax in dorsal areas and lungs are collapsed \\
\hline 3 & $\begin{array}{l}\text { Pleural effusion. Loss of detail in the ventral lung } \\
\text { lobe and cardiac silhouette. }\end{array}$ & Pleural effusion \\
\hline 4 & $\begin{array}{l}\text { Pleural effusion. Cardiac silhouette can not be } \\
\text { evaluated. }\end{array}$ & $\begin{array}{l}\text { Pleural effusion and pneumothorax in the left hemithorax at } \\
\text { the level of } T_{1}\end{array}$ \\
\hline 6 & $\begin{array}{l}\text { Pleural effusion. Cranial lung lobes filled with air, } \\
\text { caudal lobes can not be evaluated. }\end{array}$ & Pulmonary edema \\
\hline 11 & $\begin{array}{l}\text { Pleural effusion. Ventral lung lobes and cardiac } \\
\text { silhouette couldn't be evaluated. } \\
\text { Fractures at distal } 1 / 3 \text { of } 7^{\text {th }}, 8^{\text {th }} \text { and } 9^{\text {th }} \text { right ribs }\end{array}$ & Edema of the right caudal lung lobe. \\
\hline 12 & $\begin{array}{l}\text { Pleural effusion. None of the thoracic structures can } \\
\text { be recognized. }\end{array}$ & Bilateral pleural effusion \\
\hline 16 & Ventrodorsal tracheal collapse at the level of $\mathrm{T}_{1}$ & $\begin{array}{l}\text { Tracheal collapse due to a mass lesion } 12.3 \times 5.7 \mathrm{~mm} \text { in size, } \\
\text { at dorsal of trachea, isodense with soft tissue }\end{array}$ \\
\hline 20 & $\begin{array}{l}\text { Superimposition of the dilated esophagus over the } \\
\text { trachea }\end{array}$ & Megaesophagus \\
\hline
\end{tabular}




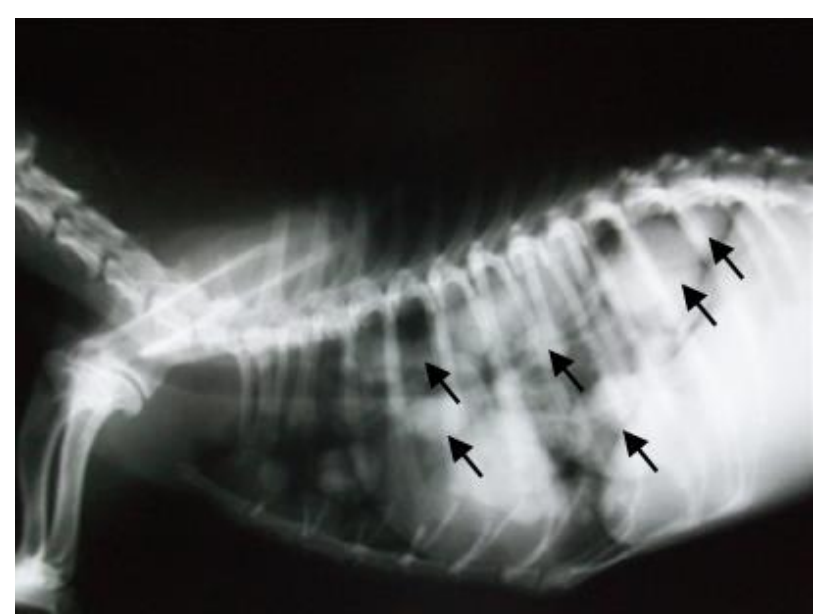

Figure 1. Right lateral radiograph of patient number 1. Arrows: Mass lesions of soft tissue opacity, diffusely spread in the lung parenchyma.

Şekil 1. 1 no'lu olguya ait lateral radyografi. Oklar: Akciğer parankiminde diffuz tarzda yayılmış yumuşak doku opasitesi veren kitlesel lezyonlar.

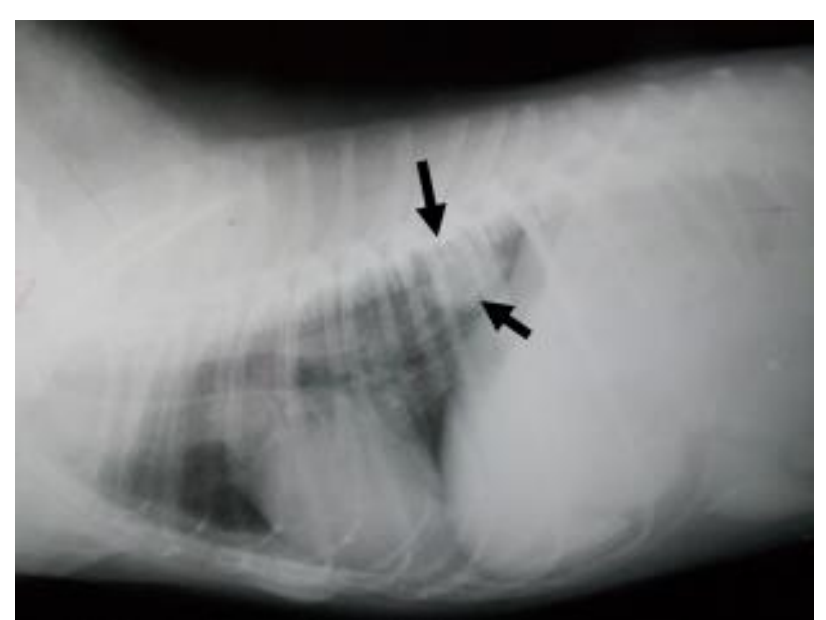

Figure 2. Right lateral radiograph of patient number 14 . Arrows: Solitary mass in the caudodorsal lung field.

Şekil 2. 14 no'lu olguya ait sağ lateral radyografi. Oklar: Kaudodorsal akciğer alanında kitlesel lezyon.

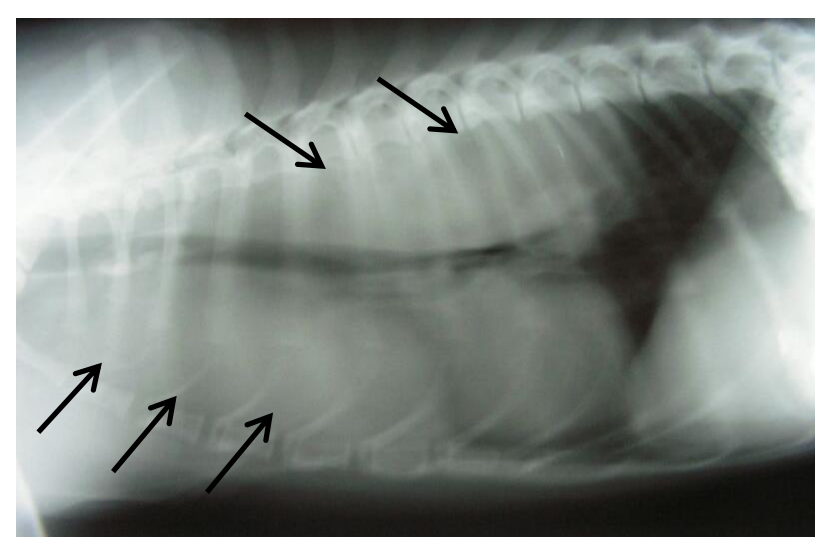

Figure 3. Left lateral radiograph of patient number 18. Arrows: Large mass suspected areas in the ventral and mid-dorsal lung field.

Şekil 3. 18 no'lu olguya ait sol lateral radyografi. Oklar: Ventral ve orta-dorsal akciğer alanlarında kitle şüpheli lezyon.

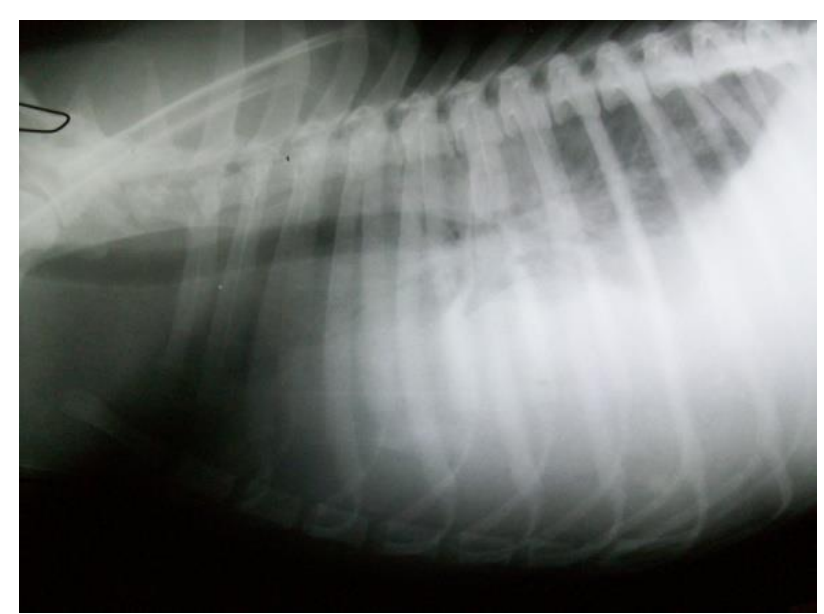

Figure 4. Right lateral radiograph of patient number 4. Loss of detail in ventral lung field and cardiac silhouette cannot be seen.

Şekil 4. 4 no'lu olguya ait sağ lateral radyografi. Ventral akciğer alanlarında detay kaybı nedeniyle kalp silüeti görülemiyor.

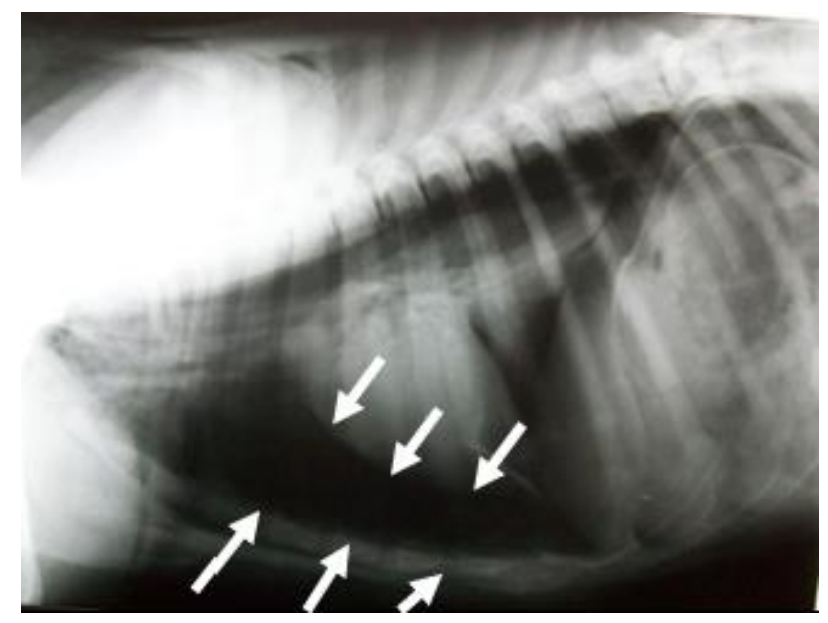

Figure 5. Left lateral radiograph of patient number 2. Cardiac silhouette is separated from the sternum. Arrows: Pneumothorax. Şekil 5. 2 no'lu olguya ait sol lateral radyografi. Kalbin sternumdan uzaklaştı̆̆ izleniyor. Oklar: Pnömotoraks.

In three of twenty cases metastatic calcified foci, isodense with bone structures were seen. In patient number 13 that showed no significant findings on radiography, metastatic nodules not larger than $10 \mathrm{~mm}$ in size were found in both left and right hemithorax (Figure 8).

In three patients hypodense areas of fluid formation were detected. Pleural effusion was present in both hemithorax of all 3 patients as diagnosed by radiographic examination. Laboratory analyses on pleural fluid showed hemorrhagic, exudative pleural effusion in two patients.

In two of twenty patients hypodense areas in the ventral lung lobes that were observed as pleural effusion on radiographs were diagnosed as pulmonary edema by CT evaluation. 
Pneumothorax was diagnosed only in one patient on radiographs, but CT examination revealed the accumulation of free gas isodense to air within the thorax in two patients. In patient number 2 the lungs were collapsed due to pneumothorax (Figure 9). Pneumothorax couldn't be detected by radiographic evaluation due to the superimposition of pleural effusion in patient number 4 (Figure 10).

In patient number 16, tracheal collapse was diagnosed by radiographic evaluation. The reason for the tracheal collapse was found to be a mass lesion that was present dorsally to trachea during CT imaging (Figure 11). According to the location of the mass, it was concluded to be an enlarged lymph node.

In patient number 20, CT revealed dilated esophagus filled with air located at the dorsal of trachea. Megaesophagus was diagnosed in the patient.

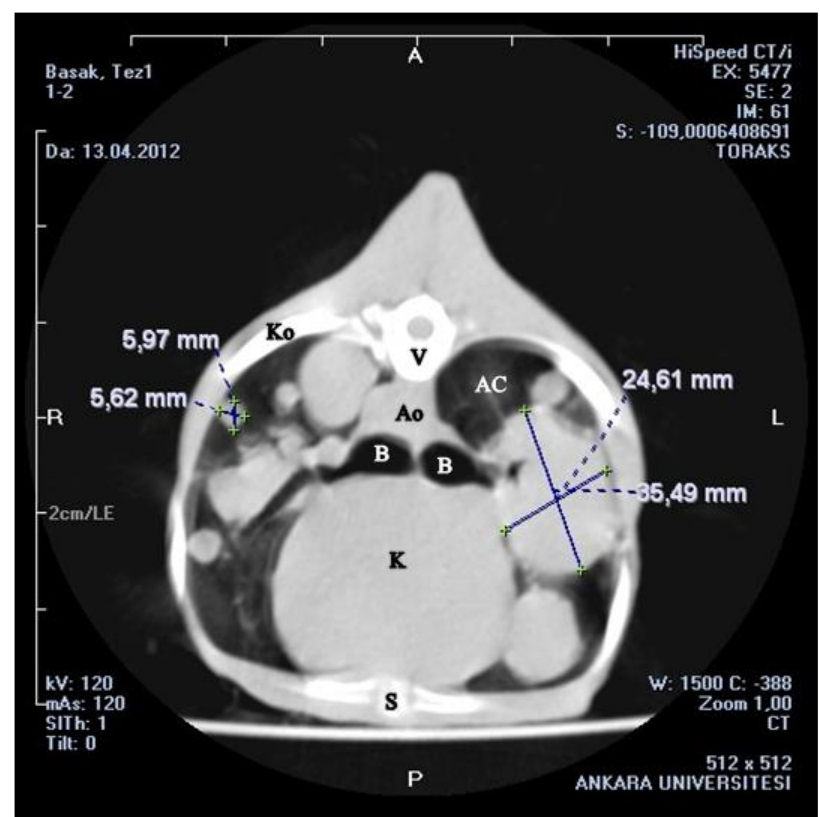

Figure 6. Transverse CT image at level of the $3^{\text {rd }}$ thoracic vertebra in patient number 1 with multiple masses in the lung parenchyma. One $24.6 \times 35.5 \mathrm{~mm}$ mass is located in the left side of the tracheal bifurcation within the lung parenchyma. Another $6.0 \times 5.5 \mathrm{~mm}$ nodule is in the right hemithorax, close to the thoracic wall. R: Right, L: Left, A: Dorsal, P: Ventral. Ao: Aorta, B: Bronchus, K: Heart, S: Sternum, Ko: Rib, AC: Lung, V: Thoracic vertebra.

Şekil 6. Akciğer parankiminde birden çok kitle bulunan 1 no'lu olguya ait 3. torakal vertebra hizasından alınan transversal BT görüntüsü. Trakeal bifurkasyon bölgesinde sol tarafta 24,6 x $35,5 \mathrm{~mm}$ boyutlarında akciğer parankiminde kitle. Sağ hemitoraksta, toraks duvarına yakın bölgede $6,0 \times 5,5 \mathrm{~mm}$ boyutlarında nodül. R: Sağ, L: Sol, A: Dorsal, P: Ventral. Ao: Aorta, B: Bronş, K: Kalp, S: Sternum, Ko: Kosta, AC: Akciğer, $\mathrm{V}$ : Torakal vertebra.

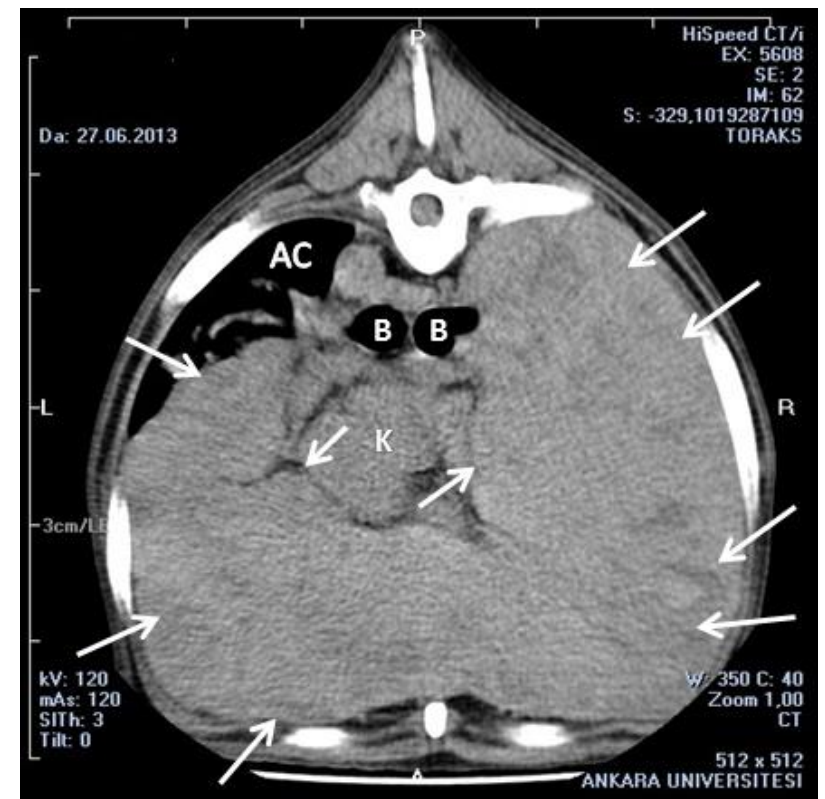

Figure 7. Transverse CT image at the level of tracheal bifurcation in patient number 18 with thymoma. Arrows: Mass structure isodense with soft tissue is totally occupying the right hemithorax and left hemithorax except dorsal areas. Mediastinum window. R: Right, L: Left, A: Ventral, P: Dorsal. AC: Lung, B: Bronchus, K: Heart.

Şekil 7. Timoma tanısı konulan 18 no'lu olgunun trakeal birfurkasyon seviyesinde alınan transversal BT görüntüsü. Oklar: Sağ hemitoraksı kaplayan ve sağ hemitoraksta dorsalde akciğer parankimi dışında tüm alanı kaplayan yumuşak doku ile izodens kitle tespit edildi. Mediastinum penceresi. R: Sağ, L: Sol, A: Ventral, P: Dorsal. AC: Akciğer, B: Bronş, K: Kalp.

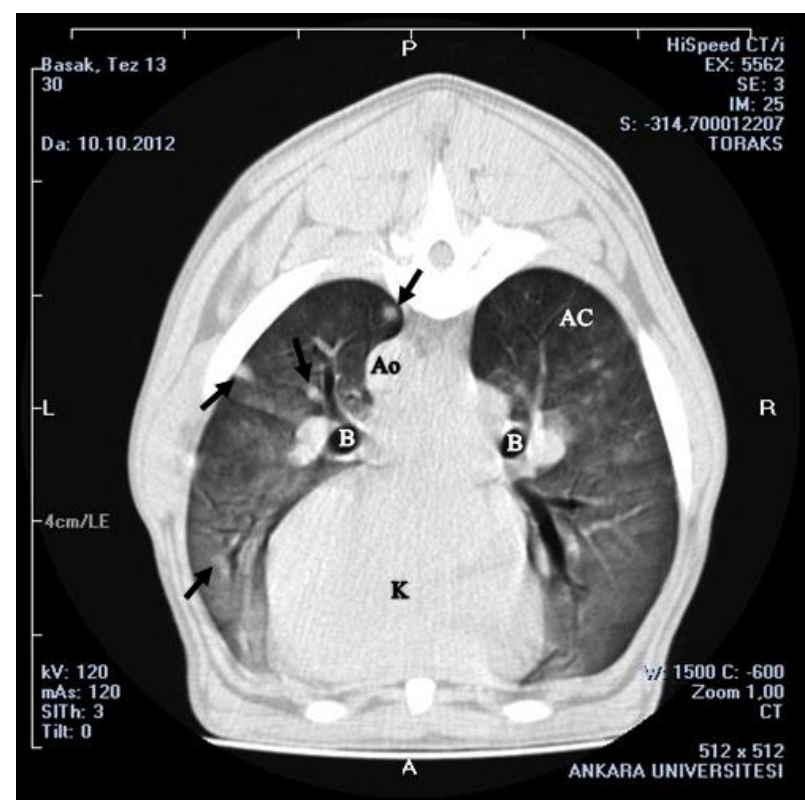

Figure 8. Transverse CT image at level of the $5^{\text {th }}$ thoracic vertebra in patient number 13 with lymphoma metastasis. Arrows: Hypodense calcified foci in cranial and middle left lung lobe. R: Right, L: Left, A: Ventral, P: Dorsal. AC: Lung, Ao: Aorta, B: Bronchus, K: Heart.

Şekil 8. Lenfoma metastazı bulunan 13 no'lu olguya ait 5. torakal vertebra seviyesinde alınan transversal BT görüntüsü. Oklar: Sol kraniyal ve sol orta akciğer lobunda hipodens kalsifiye odaklar izlendi. R: Sağ, L: Sol, A: Ventral, P: Dorsal. AC: Akciğer, Ao: Aorta, B: Bronş, K: Kalp. 


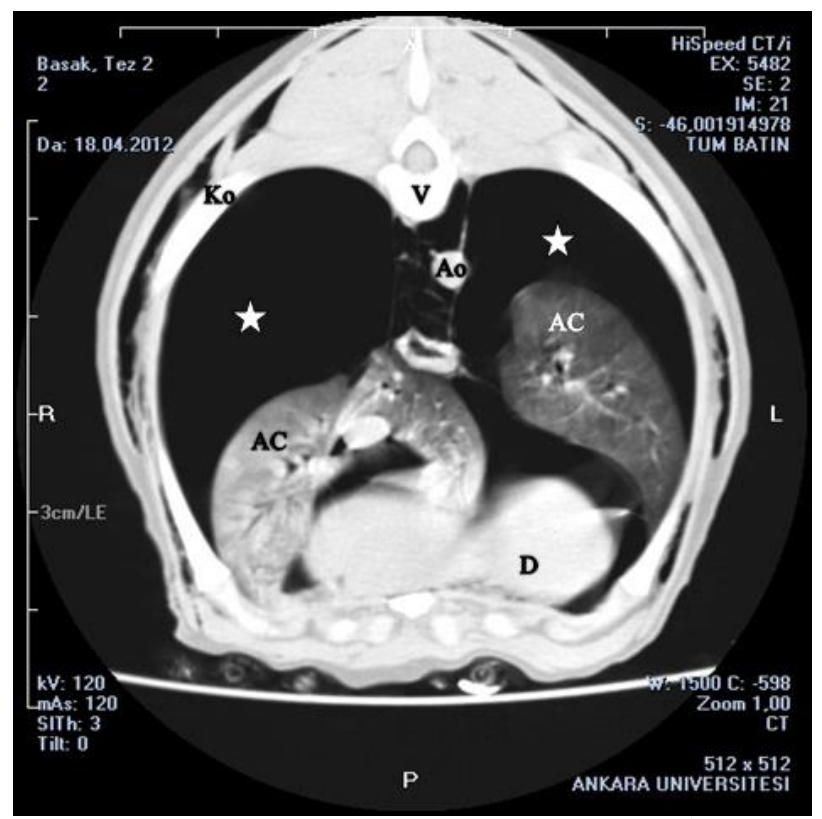

Figure 9. Transverse CT image at level of the $7^{\text {th }}$ thoracic vertebra in patient number 2 with pneumothorax. Asterix: Free gas areas. R: Right, L: Left, A: Dorsal, P: Ventral. Ao: Aorta, D: Diaphragm, Ko: Costa, AC: Lung, V: Thoracic vertebra.

Şekil 9. Pnömotoraks tanısı konulan 2 no'lu olguya ait 7. torakal vertebra seviyesinde alınan transversal BT görüntüsü. Yıldız: Serbest gazın olduğu alanlar. R: Sağ, L: Sol, A: Dorsal, P: Ventral. Ao: Aorta, D: Diyafram, Ko: Kosta, AC: Akciğer, $\mathrm{V}$ : Torakal vertebra.

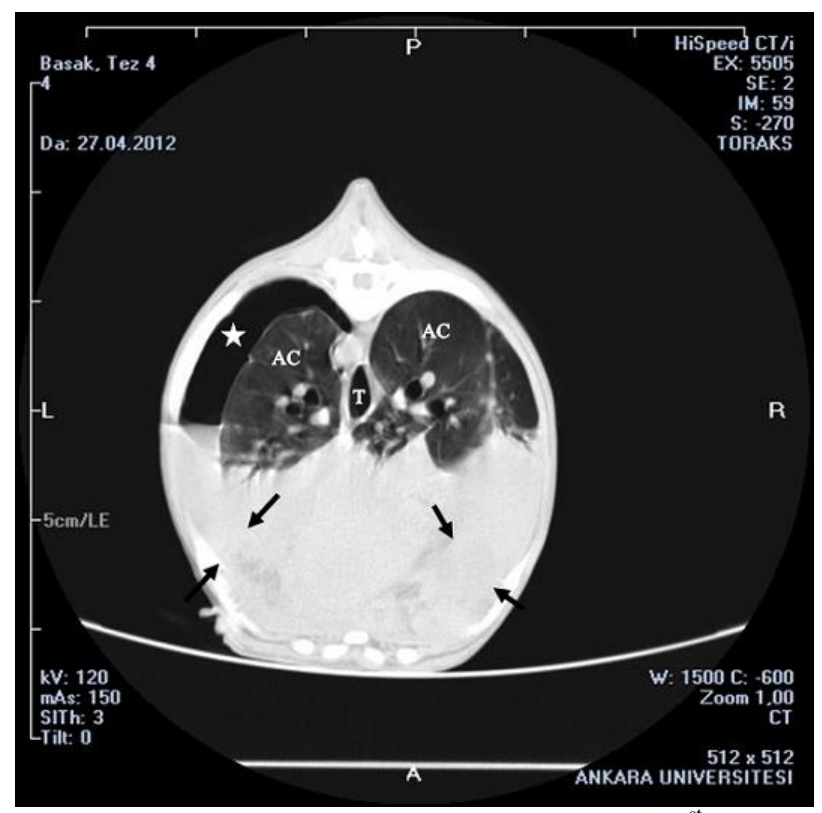

Figure 10. Transverse CT image at level of the $1^{\text {st }}$ thoracic vertebra in patient number 4 with pleural effusion and pneumothorax. Asterix: Pneumothorax in left hemithorax. Arrows: Bilateral pleural effusion in ventral thorax. R: Right, L: Left, A: Ventral, P: Dorsal. AC: Lung, T: Trachea.

Şekil 10. Plöral efüzyon ve pnömotoraks tanısı konulan 4 no'lu olguya ait 1. torakal vertebra seviyesinde alınan transversal BT görüntüsü. Yıldız: Sol hemitoraksın dorsalinde pnömotoraks. Oklar: Toraksın ventralinde bilateral plöral efüzyon görüntüsü. R: Sağ, L: Sol, A: Ventral, P: Dorsal. AC: Akciğer, T: Trakea.

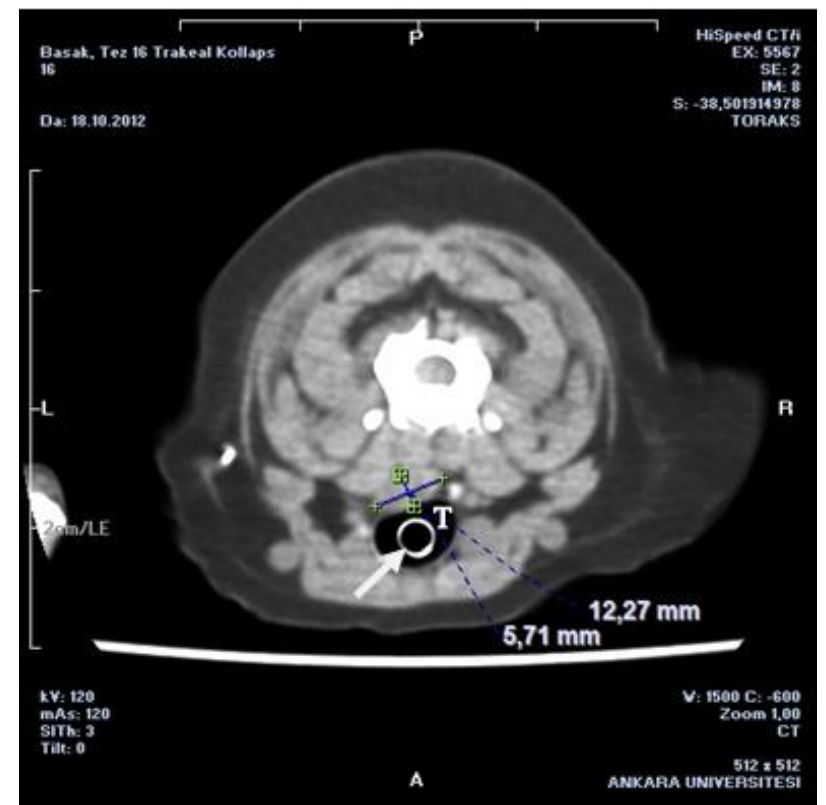

Figure 11. Transverse CT image at thoracic inlet level in patient number 16 with tracheal collapse. $12.3 \times 5.7 \mathrm{~mm}$ mass lesion at dorsal of trachea, isodense with soft tissue that caused tracheal collapse. Arrow: Endotracheal tube. R: Right, L: Left, A: Ventral, P: Dorsal. T: Trachea.

Şekil 11. Trakeal kollaps tanısı konulan 16 no'lu olguya ait toraks girişi seviyesinde alınan transversal BT görüntüsü. Trakeal kollapsa neden olan, trakeanın dorsalinde yumuşak doku ile izodens 12,3 x 5,7 mm boyutlarında kitlesel lezyon tespit edildi. Ok: Endotrakeal tüp. R: Sağ, L: Sol, A: Ventral, P: Dorsal. T: Trakea.

\section{Discussion and Conclusion}

Radiographic examination is the most preferred imaging technique for thoracic and pulmonary diseases in companion animals (21). Radiography is a quick process and has low cost compared to other diagnostic techniques. In most cases it does not require general anesthesia. Superimposition of some pathologic lesions is reported to be the disadvantage of this method $(4,24)$.

Although radiography is a preferred imaging method with its ease of use, it is very difficult to interpret thoracic radiographs. Major reasons reported for this are different presentations of normal anatomic structures ranging from gas to mineral/bone opacity, the variety of different breed related appearances and different diseases showing similar radiographic changes $(13,18)$.

Abnormal accumulation of liquids of any kind within the pleural cavity is called pleural effusion (5). Radiography is the most widely used imaging modality for the diagnosis of pleural effusion. It provides information about the severity of the effusion; but it is inadequate for identifying the underlying cause (20). It was reported in previous studies that pleural effusion prevents the display of the organs in the thoracic cavity thus making it difficult to evaluate radiographic examination and to understand the underlying cause of the disease $(15,17)$. In five of the patients (Patient no: 3 , 
$4,6,11,12)$ thoracic structures couldn't be evaluated due to pleural effusion.

Johnson and Wisner (9) reported that pleural effusion can be diagnosed by radiography, but in order to understand the cause of effusion, CT is indicated. Intrathoracic mass lesions, e.g. hemangiosarcoma, can be sources of pleural effusion; in these cases it is stated that CT can be a guide for the treatment $(7,9)$. In our study, for diagnosis of pleural effusion radiographic evaluation was enough and CT findings did not provide additional information about the cause of the pleural effusion in any case because the cause of the effusion was not due to mass formations. CT gave detailed information about the location, amount of the effusion and it was useful in assessing the condition of the lung lobes.

Pneumothorax is defined as the accumulation of free gas within the pleural cavity. It can occur spontaneously or due to a trauma $(14,16,22)$. CT is a useful diagnostic method for determination of the source of pneumothorax and how it affects the lung parenchyma $(21,23)$. In this study, severe pneumothorax in one patient was diagnosed by radiographic examinations as reported in previous studies $(10,11,21)$. In this patient CT drew attention to the collapse of the lung lobes due to pneumothorax and was helpful for needle aspiration of the pneumothorax by displaying the exact location of the free gas. Only in one patient (Patient number 4) pneumothorax couldn't be diagnosed by radiography because of the pleural effusion hiding the free gas that was present. In that patient diagnosis was made by CT examination as it can provide transversal images and superimposition was not a problem.

Nemanic et al. (12) reported that pulmonary nodules must be $7-8 \mathrm{~mm}$ in diameter to be detected by radiographic examination, though nodules as small as 1 $\mathrm{mm}$ can be determined by CT examination. In the same publication it was stated that only $9 \%$ of the pulmonary masses detected by CT, could be determined also by radiographic evaluation. In patient number 13, thorax was evaluated as normal on radiographic examination, but during CT imaging calcified foci smaller than 7-8 $\mathrm{mm}$ in size were found in the lung parenchyma. These findings were in compliance with previous studies (12). By the help of CT imaging, mass formations could be evaluated at an early stage and false positive results of mass formations were prevented leading to an accurate treatment protocol.

Pulmonary calcifications are determined as radiopaque lesions, developing in the lung parenchyma and are characterized by accumulation of calcium crystals $(2,6,19)$. Increased opacity due to mineralization in mass lesions can sometimes be confused with pulmonary masses with calcification such as granuloma and osteosarcoma $(1,6,25)$. In this study lesions evaluated as radiopaque foci on radiography were found to be nodules in patient number 8 and 10 . Nodules or mass formations can be separated from pulmonary calcifications as they are found isodense with soft tissue during CT examination.

Tracheal collapse is a progressive, degenerative disease of tracheal rings commonly seen in middle-aged or elderly dogs (5). Radiography is used primarily for the diagnosis of tracheal diseases $(10,24)$. Radiographic examination was satisfactory for the diagnosis in one patient with tracheal collapse. CT examination was made for understanding the reason that lead the trachea to collapse. Through CT examination, the reason for the collapse was determined.

For an initial diagnosis of severe phases of some thoracic and lung diseases like pneumothorax, pleural effusion or masses, radiographic examination is satisfactory, but it gives a limited information about the cause, exact location of the lesion and the condition of the surrounding tissues. If a surgical attempt is planned or more detailed information is needed, CT examination can be performed. In this study CT examination was helpful to detailed diagnosis of small sized nodules that couldn't be seen on thoracic radiographs. The superiority of CT to radiography was concluded by CT's ability to provide cross-sectional images, measurements on lesions, detailed information about exact location and the effects of the lesion on surrounding tissue or organs.

\section{References}

1. Ballegeer EA, Adams WM, Dubielzig RR, et al. (2010): Computed tomography characteristics of canine tracheobronchial lymph node metastasis. Vet Radiol Ultrasound, 51, 397-403.

2. Beukers M, Grosso FV, Voorhout G (2013): Computed tomographic characteristics of presumed normal canine abdominal lymph nodes. Vet Radiol Ultrasound, 54, 610617.

3. Burk RL, Feeney DA (2003): Small Animal Radiology and Ultrasonography. Chapter: 2. 25-44. Saunders, USA.

4. Diana A, Pivetta M, Cipone M (2006): Imaging evaluation of the small animal mediastinum. Vet Res Commun, 30, 145-151.

5. Ettinger SJ, Feldman EC (2010): Textbook of Veterinary Internal Medicine. $7^{\text {th }}$ Edition, 10-150. Saunders, USA.

6. Farrow CS (2003): Veterinary diagnostic imaging: The dog and cat. Chapter 36. 368-383. Mosby, USA.

7. Fina C, Vignoli M, Terragni R, et al. (2014): Computed tomographic characteristics of eosinophilic pulmonary granulomatosis in five dogs. Vet Radiol Ultrasound, 55, 16-22.

8. Gough A (2007): Differential Diagnosis in Small Animal Medicine. 193-214. Blackwell Science, UK.

9. Johnson EG, Wisner ER (2007): Advances in respiratory imaging. Vet Clin North Am Small Anim Pract, 37, 879900.

10. Kealy JK, McAllister H (2011): Diagnostic Radiology and Ultrasonography of the Dog and Cat. 149-192. Saunders, USA. 
11. Miller CJ (2007): Approach to the respiratory patient. Vet Clin North Am Small Anim Pract, 37, 861-878.

12. Nemanic S, London CA, Wisner ER (2006): Comparison of thoracic radiographs and single breath-hold helical CT for detection of pulmonary nodules in dogs with metastatic neoplasia. J Vet Intern Med, 20, 508-515.

13. Otoni CC, Rahal SC, Vulcano LC, et al. (2010): Survey radiography and computerized tomography imaging of the thorax in female dogs with mammary tumors. Acta Vet Scand, 52, 20.

14. Parry A, Lamb C (2012): Radiology of thoracic trauma in the dog and cat. In Practice, 32, 238-246.

15. Rademacher N, Pariaut R, Pate J, et al. (2014): Transthoracic lung ultrasound in normal dogs and dogs with cardiogenic pulmonary edema: a pilot study. Vet Radiol Ultrasound, 55, 447-52.

16. Rivero MA, Ramirez JA, Vazquez JM, et al. (2005): Normal anatomical imaging of the thorax in three dogs: Computed tomography and macroscopic cross sections with vascular injection. Anat Histol Embryol, 34, 215-219.

17. Rodriguez-Panadero F, Janssen JP, Astoul P (2006): Thoracoscopy: general overview and place in the diagnosis and management of pleural effusion. Eur Respir J, 28, 409-421.

18. Saunders JH, Vanbree H (2003): Comparison of radiography and computed tomography for the diagnosis of canine nasal aspergillosis. Vet Radiol Ultrasound, 44, 414-419.
19. Saunders JH, Zonderland J, Clercx C, et al. (2002): Computed tomographic findings in 35 dogs with nasal aspergillosis. Vet Radiol Ultrasound, 43, 5-9.

20. Schultz RM, Petersy J, Zwingenberger A (2009): Radiography, computed tomography and virtual bronchoscopy in four dogs and two cats with lung lobe torsion. J Small Anim Pract, 50, 360-363.

21. Schwarz T, Johnson V (2008): BSAVA Manual of Canine and Feline Thoracic Imaging. 5-72. BSAVA Publishing, UK.

22. Schwarz T, Saunders J (2011): Veterinary Computed Tomography. 261-275. Wiley-Blackwell, UK.

23. Schwarz LA, Tidwell AS (1999): Alternative imaging of the lung. Clin Tech Small Anim Pract, 14, 187-206.

24. Thrall DE (2002): Textbook of veterinary diagnostic radiology. Chapter 5. 42-56. Elsevier, USA.

25. Tsai S, Sutherland-Smith J, Burgess K, et al. (2012): Imaging characteristics of intrathoracic histiocytic sarcoma in dogs. Vet Radiol Ultrasound, 53, 21- 27.

Geliş tarihi:10.02.2015 / Kabul tarihi:30.11.2015
Address for correspondence:
Dr. Başak Boztok ÖZGERMEN
Aksaray Üniversitesi, Veteriner Fakültesi
Cerrahi Anabilim Dall, Merkez Kampüs,
Aksaray/ Türkiye.
e-mail:basak1607@gmail.com 